\title{
MAZHAB-MAZHAB ILMU NAHWU DALAM SASTRA ARAB KLASIK
}

Taufik, S.Ag., M.A

(taufik16sps@gmail.com)

(Guru Madya Bahasa Arab di MAN 2 Kota Bima)

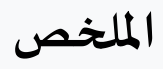

ستحلل هذه الورقة بشكل وصفي تاريخ تطور المدارس في العلوم النحوية في الديناميكيات التاريخية للعالم النحوي العربي. يعتبر علم النحو تخصصًا شائعًا في العالم الإسلامي علمًا كلاسيكيًا وفريدًا مع الفروق الدقيقة في التأثير الفلسفي اليوناني. تستخدم منهجية التجميع منطقًا معقدًا مع القياس ومن ثم يتم تجميع صياغة القواعد المتفق عليها لتوجيهها نظريًا وعمليًا. كان ظهور علم النحوة لا ينفصل عن الدعم القوي لعلي بن أبي طالب والمبادرة الرائعة لأب النحوة أبو أسود الدوالي في تجميع أساسيات العلم وطورها علماء النهو الذين ظهروا بعد ذلك. انبثقت هذه المعرفة من خلفية ظهور "اللحن" و "الغلاد" التي حدثت في المجتمع المسلم في ذلك الوقت مع التوجـ الأولي المتمثل في الحفاظ على نقاء اللغة العربية كلغة القرآن. هناك ثلاثة عوامل على الأقل تكمن خلفيات ولادة النحو: العامل الدينية والعامل الاجتماعياة والعامل السياسية. في مجال العلوم أنتج علماء مؤهلين ولديهم شخصيات منهجية غير متجانسة ولديهم خلفيات أيديولوجية دينية واجتماعية ثقافية متنوعة. ظهرت مدرسة النحو وسبقتها مدرساالبصرة والكوفة ثم بغداد ومصر (سوريا) والأندلس. ولدت مدرسا البصرة والكوفة ، بصفتهما المدارس الرئيسية ، لإلهام المدارس الأخرى ، مما أضياف إلى الكنوز الفكرية لتطوير علم النحو.

الكلمات المفتاحية: علم النحوة ، الخلفية التاريخية ، المدرسـة النحوية ، شخصياتها.

Tulisan ini akan menganalisis secara deskriptif tentang sejarah perkembangan mazhab dalam Ilmu Nahwu dalam dinamika historis dunia gramatikal Arab. Ilmu Nahwu sebagai sebuah disiplin ilmu yang populer di dunia Islam adalah sebuah ilmu klasik dan unik serta bernuansa pengaruh filsafat Yunani. Metodologi penyusunannya menggunakan logika yang rumit dengan analogi (qiyas) kemudian disusunlah sebuah formulasi kaidah-kaidah yang disepakati menjadi pedoman secara teoretis dan praktis.

Kemunculan Ilmu Nahwu tidak terlepas dari support yang kuat dari Ali bin Abi Thalib sebagai khalifah dan prakarsa brilian seorang bapak Ilmu Nahwu Abu Aswad al-Duali memulai menyusun dasar-dasar keilmuan dan dikembangkan oleh ulama-ulama Nahwu yang muncul sesudahnya. Ilmu ini muncul dilatarbelakangi muculnya "lahn" dan "ghalad" yang terjadi di kalangan masyarakat Islam saat itu dengan orientasi awal memelihara kemurnian bahasa Arab sebagai bahasa al Qur'an. 
Setidaknya ada tiga faktor yang melatari lahirnya nahwu : faktor religius, faktor sosilogis dan faktor politik.

Dalam disiplin Ilmu Nahwu telah melahirkan ulama-ulama yang mumpuni dan memiliki karakter metodologis yang heterogen serta latar belakag ideologi kegamaan dan sosiokultural beragam pula. Mazhab nahwupun muncul diawali oleh mazhab Bashrah dan Kufah kemudian diikuti oleh Baghdad, Mesir dan Andalusia. Mazhab Bashrah dan Kufah sebagai mazhab utama lahir menginspirasi mazahab-mazhab lain, menambah khazanah intelektual bagi pengembangan ilmu Nahwu.

Keywords: Ilmu Nahwu, latar belakang sejarah, mazhab Nahwu, tokoh-tokohnya.

\section{A. PENDAhuluan}

Bahasa Arab merupakan salah satu bahasa mayor di dunia yang dituturkan oleh lebih dari 200.000.000 umat manusia ${ }^{1}$, selain itu ia juga merupakan bahasa alquran dan merupakan bahasa yang sangat agung dan juga memiliki banyak cabang ilmu seperti ilmu balaghah, ilmu nahwu, ilmu sharaf, dan lain banyak lagi. Adapun ilmu nahwu adalah satu dari ilmu gramatika Arab yang harus dipelajari oleh setiap pembelajar bahasa Arab, di samping ilmu-ilmu lain seperti sharaf (morfologi). Karena pemahaman yang baik mengenai ilmu nahwu tentunya akan menghantarkan seseorang pada kemudahan berkomunikasi dengan menggunakan bahasa Arab.

Secara etimologis kata “nahwu” berasal dari kata نحوا - ينحو - نحا dengan arti arah (jihat), jalan (thañq), contoh (mislu), ukuran (miqdār), dan tujuan (qashdu). ${ }^{2}$ Sedangkan secara terminologis definisi nahwu, seperti yang disebutkan oleh al- Hibān, yang dikutip Ibrahim Mustafa dalam kitabnya, yaitu suatu ilmu yang mempelajari keadaan-keadaan dari akhir kata, I'rab atau bina ${ }^{3}$ Definisi lebih lengkap Al-Hasyimi bahwa ilmu nahwu adalah kaidah-kaidah untuk mengetahui keadaan akhir kata dalam bahasa Arab yang terbentuk dari tarkib satu kata dengan kata lainnya dalam hal I'rab dan bina serta yang mengikutinya. ${ }^{4}$ Ibnu Jinnī menyebutkan bahwa ilmu nahwu adalah "menuju cara bicara orang Arab, dalam hal perubahan pada i'rab dan lainnya, seperti tastniyah, jama', tahqīr, taksì $r$, idhāfah, nasab, tarkīb dan lainnya; agar orang yang bukan berbahasa Arab bisa meniru kefasihan orang Arab. ${ }^{5}$

\footnotetext{
${ }^{1}$ Azhar Arsyad, Bahasa Arab dan Metode Pengajarannya (Yogyakarta; Pustaka Pelajar, 2004), 1.

${ }^{2}$ Al-Munjid fi al-Lughah, cet. 44. (Beirut : Dār al-Masyriq, 2011) 795. Arif Rahman Hakim, "Mempermudah Pembelajaran Ilmu Nahwu pada Abad 20”, Jurnal al-Maqoyis, vol. 1 No. 1, Jan-Juli 2013.

${ }^{3}$ Ibrahim Mushtafa, Ihya al-Nahwi, 1.

Pdf. http://ia600506.us.archive.org/10/items/ihhhihhh/Ehyau_Nahw_1.pdf.

${ }^{4}$ Ahmad al-Hasyimi, al-Qawaid al-Asasiyyah li al-Lughat al-Arabiyyah, 6,

${ }^{5}$ Ibnu Jinnī, al-Khasāish, (Kairo : Dār al-Hadits: 2008), 78.
} 
Menurut Al-Gulayaini (dalam Pengantar Studi Linguistik Arab) dikutip Wahyuning Sari bahwa ilmu nahwu adalah dalil-dalil yang memberitahukan kepada kita bagaimana seharusnya keadaan akhir kata-kata itu setelah tersusun dalam kalimat, atau ilmu yang membahas kata-kata arab dari I'rab dan bina ${ }^{6}$. Nahwu adalah salah satu cabang ilmu pengetahuan yang mengementari I'rab atau baris akhir suatu kata, apabila suatu kata tersusun dalam struktur kalimat atau al-jumlah. ${ }^{7}$ Sedangkan Ilmu Sharaf adalah Ilmu untuk memindahkan atau mengubah suatu kata asal kepada berbagai bentuk kata. ${ }^{8}$

Sebagai kesimpulan dari beberapa definisi di atas, penulis dapat meringkas definisi Ilmu Nahwu adalah ilmu dasar untuk menentukan syakl (fathah, kasroh, dhomah atau sukun) sehingga dapat mengetahui kedudukan kata dalam kalimat sehingga pembaca/pembelajar dapat membaca teks-teks bahasa Arab dengan baik. Sedangkan ilmu Sharaf adalah ilmu untuk dapat menentukan bentuk kata tersebut dan menentukkan asal suatu kata dan perubahan-perubahan dalam bentukbentuk yang lain (derivasi). ${ }^{9}$

Pada awal kemunculannya, nahwu dimaksudkan hanya sebagai sarana belajar untuk mengantisipasi meluasnya kesalahan berbahasa. Namun pada perkembangannya, nahwu justru menjadi sebuah disiplin ilmu yang mandiri, terlepas dari ilmu lain, dan banyak dipengaruhi oleh "euforia" filsafat Yunani sehingga ilmu ini rumit dan berbelit-belit. ${ }^{10}$

\section{B. LATAR BELAKANG LAHIRNYA ILMU NAHWU}

Seiring meluasnya wilayah Daulah Islamiyah dan semakin banyak pula percampuran antara orang Arab asli dan kaum lain di luar Arab. Seperti telah disebutkan di atas, mereka mulai menggunakan bahasa Arab dalam percakapan mereka, dan dari sinilah mulai terlihat beberapa penyimpangan dalam bahasa Arab. Permasalahan ini sangat mengganggu dan menimbulkan banyak kekhawatiran di antara para pemikir Arab, sehingga para ulama berusaha untuk menemukan solusi dari masalah yang jika dibiarkan akan mempengaruhi kelestarian bahasa Arab itu sendiri.Imam Ali

\footnotetext{
${ }^{6}$ Ana Wahyuning Sari, “Analisis Kesulitan Pembelajaran Nahwu Pada Siswa Kelas VII MTs Al Irsyad Gajah Demak Tahun Ajaran 2015/2016" Lisanul Arab Journal of Arabic Learning and Teaching. Jilid 6. Vol.1. 2017.

${ }^{7}$ Ahmad al-Hasyimy, al-Qawaidul al-Asasiyyah, (Beirut : Dar al-Kutub al-Ilmiyah, t.t) ,.6. Dalam : Sudirman, "Pemikiran Nahwu Al-Zamakhsyary Dalam Persfektif Alquran".

${ }^{8}$ Hazarudin, Bahasa Arab Teoritis (Nahwu Sharaf) (Bogor: CV. Bintan Tsurayya, 1994) 2. Lihat dalam : Ahmad Marzuq, "Grammatical Errors in the Arabic Essay (Content Analysis Research on the Student of Arabic Language Education Department, Faculty of Languages and Arts, StateUniversity of Jakarta)", 1-7.

${ }^{9}$ Taufiq Burj, Musykilat Ta'lim al-Arabiyyah Li Ghairi an-Nathiqina biha, dalam as-Sijl al-Ilm Li-Nadwah alAlamiyah Li Ta'lim al-Arabiyyah Li Ghairi an-Nathiqina biha, (Kairo: Dar al-Ma'arif, 1980.) 129.

${ }^{10}$ Umi Nurun Ni'mah, "Dasar-Dasar Penyusunan Nahwu Syauqi Dhaif (Kajian Epistemologis atas Karya Syauqi Dhaif Tajdid an-Nahwu dan Taisir an-Nahwu at-Ta'limy Qadiman wa Haditsan)", dalam Adabiyyat Jurnal Bahasa dan Sastra Arab Vol.6, No. I Maret 2007, 63.
} 
bin Abi Thalib menjadi salah satu yang paling bertanggung jawab pada masa tersebut, karena beliau adalah seorang khalifah dan pemimpin daulah Islamiyah. Maka sudah sewajarnya jika beliau menjadi orang yang pertama kali memikirkan cara untuk menyelesaikan masalah ini. Apalagi beliau adalah orang yang sangat mengerti tentang fashahah dan balaghah, maka beliau tidak bisa tinggal diam dalam menghadapi masalah ini. Tetapi karena pada saat itu beliau sedang disibukkan dengan urusan peperangan yang terjadi dalam negeri yang tidak bisa ditinggalkan, maka beliau memilih salah satu muridnya, Abu al-Aswad ad-Du'ali. ${ }^{11}$ Adapun faktor lain yang menjadi penyebab munculnya gagasan penyusun ilmu nahwu adalah faktor peradaban, yaitu masa di saat agama Islam masuk dalam dunia Arab.

Perkembangan ilmu nahwu dalam abad pertama hijriyah ini dimulai dari kota Bashrah yang kemudian meluas hingga ke kota Mekkah atas peran Ibnu Abbas dan ke kota Madinah atas peran Abdurrahman bin Hurmuz al-Madani. Begitulah ilmu nahwu tersebar dan berkembang di banyak kota bahkan negara dari abad pertama hijriyah hingga sekarang. Semakin meluasnya ekspansi Islam ke negara-negara timur tengah yang disebabkan karena penaklukan yang terjadi pada khalifah Ali bin Abi Thalib dan semakin banyaknya orang ajamy ${ }^{12}$ yang memeluk agama Islam menyebabkan bertambahnya lahn ${ }^{13}$ dan juga galath atau kesalahan karena orang ajamy yang juga belum pernah berbahasa dengan bahasa Arab. Kesalahan-kesalahan tersebut semakin menguatkan akan kebutuhan mengenai dirumuskannya dasar kaidah dalam bahasa Arab, sehingga dapat meminimalisir kesalahan yang terjadi. Selain itu, tujuan penting dari dirumuskannya dasar kaidah bahasa Arab adalah untuk menjaga Alquran dan juga sunnah nabi dari berbagai macam kesalahan dan penyimpangan.

Bahasa Arab mempunyai kaidah-kaidah tersendiri di dalam mengungkapkan atau menuliskan sesuatu hal, baik berupa komunikasi maupun informasi. Lalu, bagaimana sebenarnya awal mula terbentuknya kaidah-kaidah ini, dan mengapa dikatakan dengan istilah nahwu?. Pada zaman jahiliyah, kebiasaan orang-orang Arab ketika berucap atau berkomunikasi dengan orang lain, mereka melakukannya dengan karakternya masing-masing. Lafazh-lafazh yang muncul terbentuk

11 ،Abdul Hadi Fadli. Marâkiz al-Dirâsat al-Nahwiyyah. (Yordania; Makatabah al- Manar 1986), 7.

12 'Ajamy adalah istilah untuk penyebutan orang atau masyarakat di luar orang Arab atau masyarakat Arab.

${ }^{13}$ Lahn adalah kesalahan di dalam berbahasa. Persoalan "Lahn" sebenarnya telah mulai muncul sejak Nabi saw masih ada. terjadi pula pada masa al-Khulafa' al-Rasyidun. tetapi lahn baru menjadi perhatian dan kesadaran kolektif terjadi pada masa pemerintahan Bani Umayyah dimana pada masa ini yang membuat kesalahan berbahasa (lahn) tidak saja kalanagan masyarakat awam, bahkan kalangan yang dianggap ahli bahasa juga melakukan hal yang sama. Lihat Said al-Afghani, Min Târîkh al-Nahwi, (Beirut: Dar al-Fikr, t.t.), 8-9. Dikutip oleh : Toni Pransiska, “ Konsep I'rab dalam Ilmu Nahwu (Sebuah Kajian Epistemologis)”, al-Mahāra, Vol. 1, No.1, Desember 2015/1437H. Bandingkan dengan : Yeni Ramdiani, "Kajian Historis; Perkembangan Ilmu Nahwu Mazhab Basrah", Volume VIII Nomor 2 Juli Desember 2015. 
berdasarkan peraturan yang telah ditetapkan, di mana para junior belajar kepada senior, para anak belajar bahasa kepada orang tuanya dan seterusnya. Namun ketika Islam datang dan menyebar ke negeri Persia dan Romawi, terjadilah pernikahan orang Arab dengan orang non Arab, serta terjadi pula perdagangan dan pendidikan. Hal ini menjadikan bahasa Arab bercampur baur dengan bahasa non Arab. Orang yang fasih bahasanya menjadi jelek dan banyak terjadi salah ucap, sehingga keindahan bahasa Arab menjadi rusak bahkan hilang. ${ }^{14}$

Jadi kondisi inilah yang mendorong dilakukannya penyusunan kaidah-kaidah yang disimpulkan dari ucapan orang Arab yang fasih lalu dijadikan rujukan dalam memberi harakat huruf akhir setiap kata. Muncullah ilmu yang pertama kali disusun untuk menghindarkan bahasa Arab dari kerusakan, yang disebut dengan ilmu Nahwu. Adapun orang yang pertama kali menyusun ilimu tentang kaidah-kaidah bahasa Arab adalah Abu al-Aswad al-Duali dari Bani Kinanah atas dasar perintah Khalifah Ali Bin Abi Thalib. Terdapat suatu kisah yang dinukil dari Abu al-Aswad alDuali, bahwasanya ketika sedang berjalan-jalan dengan putrinya pada malam hari, lalu sang anak menghadapkan wajahnya ke langit dan menyaksikan betapa indahnya benda-benda yang dilihatnya berupa bintang-bintang. Kemudian mengungkapkan perasaan kagumnya dengan perkataan :

“apakah yang paling indah di langit?” tanpa menyadari bahwa dengan mengkasrah huruf hamzah berarti menunjukkan kalimat tanya. Sehingga sang ayah berkata sebagai jawaban نُجُوْمُهَايابنية (bintang-bintangnya, anakku). Namun sang anak menyanggah dengan mengatakan


kalau begitu ucapkanlah, مَا أَحسَنَ الستّمَاءَ (betapa indahnya langit). ${ }^{15}$

Pada pagi hari, Abu al- Aswad al-Duali menghadap Ali bin Abi Tholib sebagai khalifah dan melaporkan kepadanya percakapan yang terjadi dengan putrinya, intinya sesuatu yang tidak dipahaminya. Imam Ali berkata; Ini adalah akibat bercampurnya bahasa Ajam (non Arab) dan Bahasa Arab. Khalifah memerintahkan Abu al-Aswad al-Duali untuk membuat aturan bahasa. Abul Aswad lalu membeli sehelai kertas dan setelah beberapa hari beliau menulis di atasnya pembagian kalimat yang terdiri dari tiga bagian, yaitu isim, fi'l dan harf serta ditambah ta'ajjub kemudian tulisan itu disodorkan pada Imam Ali. Lalu Imam Ali berkata: Inha nahwa haadza (buatkan contoh

\footnotetext{
${ }^{14}$ Syauqiy Dhaif, al-Madaris al-Nahwiyah, Cet. III, (Beirut: Dar al-Ma'arif, t.t), 25.

${ }^{15}$ al-Thahthowiy, Nash'ah al-Lughah,(t. t), 9
} 
seperti ini), karena itulah ilmu ini dinamakan "Ilmu Nahwu"16. Dikisahkan pula bahwa ketika Abu al-Aswad al-Duali melewati seseorang yang sedang membaca al-Qur'an, mendengar qari'



Dengan mengkasrah huruf lam pada kata rasulihi, artinya "Sesungguhnya Allah berlepas diri dari orang-orang musyrik dan rasulnya.." hal ini jelas sangat merusak makna ayat tersebut dan menyesatkan. Seharusnya huruf tersebut dibaca fathah, artinya "Sesungguhnya Allah dan RasulNya berlepas diri dari orang-orang musyrik". Karena mendengar perkataan ini, Abu al-Aswad alDuali menjadi khawatir kalau keindahan bahasa Arab menjadi rusak dan keasliannya menjadi hilang, apalagi hal tersebut terjadi di awal mula daulah islamiyah. Hal ini disadari oleh khalifah Ali bin Abi Thalib, sehingga ia memperbaiki keadaan ini dengan membuat pembagian kata, bab inna dan saudaranya, bentuk idhafah (penyandaran), kalimat ta'ajjub (kekaguman), kata tanya dan أُنْحُ هَذَ النَّحْوَ , selainnya, kemudian Ali bin Abi Thalib berkata kepada Abu al-Aswad al-Duali, "Ikutilah jalan ini”. Dari kalimat inilah, ilmu tentang kaidah bahasa Arab disebut dengan ilmu nahwu. (Arti nahwu secara bahasa adalah arah). Lalu hal ini mendorong Abul Aswad berfikir untuk meletakkan kaidah-kaidah nahwu ${ }^{17}$.

Faktor-faktor yang mendorong kemunculan ilmu Nahwu menurut Ahmad al-Iskandari dan Musthafa Anani serta Syauqi Dhaif dan Nuruddin Hasan, setidaknya dipengaruhi oleh beberapa factor : (a). Faktor Agama; (b). Faktor Sosial dan; (c). Faktor Politik sebagai faktor-faktor utama yang melatar-belakangi kemunculan disiplin ilmu Nahwu, tetapi disamping itu, tambahnya, terdapat faktor utama lain yang setidaknya turut berperan didalamnya yaitu Faktor Primordial (ar. al-qawmi; ras dan kesukuan). ${ }^{18}$ Faktor lain ini tidak lebih dikarenakan karena bahasa (Arab) adalah salah satu warisan leluhur dan sekaligus menjadi kebanggaan yang harus dilestarikan. Maka, tidak mengherankan jika bangsa Arab keukeuh ingin memelihara bahasa kebanggaan mereka (Arab) daripada penyelewengan dan kesalahan yang tidak dapat ditolerir dimana konsekuensinya adalah mutlak harus dirumuskan sebuah prinsip dan pedoman bahasa yang harus dipergunakan bangsa non-Arab di dalam proses komunikasi.

\footnotetext{
${ }^{16}$ al-Thahthowiy, Nash'ah al-Lughah, (t. t), 9

${ }^{17}$ Mazin al-Mubarak, al-Nahw al-Arabiy; al-'Illah al-Nahwiyyah, Jilid III, (Dar al-Fikr, 1981), 44.

${ }^{18}$ Lihat lebih detil dalam, Nuruddin, Hasan, Al-Dalil ila Qawä id al-Lughah al-,,Arabiyyah, 14; Dlaif, Syauqi, Al-Madaris al-Nahwiyyah,12. Bandingkan juga dengan : Muhammad Husni Arafat,'Diskusi Antara Al-Sairafi Dan Bisyr Ibn Matta Di Dalam Kitab Al-Muqabasat Tentang Persoalan Nahwu" MANARUKOURANAhmad Mushtafa Al-Iskandari, Al- Wasith fi al-Adab al- Arabi wa Tarikhihi, (Kairo: Wizarat al-Ma aearif al-Umumiyyah, 1919), 9.
} 
Tokoh pertama kali meletakkan kaidah nahwu adalah Abu al-Aswad al-Duali, baik itu dengan petunjuk dari Ali bin Abu Thalib atau dicetuskan sendiri. Kemudian muncullah gerakan untuk mengarang kaidah nahwu berturut-turut sesudah itu. Dimulainya gerakan ini dengan pengaruh sebagian masalah-masalah nahwu sekitar ayat-ayat Al Qur'an dan bait-bait syair, dan dikatakan bahwa Isa bin Tsaqafi yang wafat tahun $149 \mathrm{H}$ telah mengumpulkan masalah-masalah itu dalam dua kitab yang ia berinama al- Jami' dan al-Ikmal, akan tetapi kedua kitab ini sedikitpun tidak sampai kepada kita. ${ }^{19}$ Kemudian datang sesudah itu al- Khalil bin Ahmad al-Farahidi alBusairi yang wafat pada tahun $175 \mathrm{H}$. Ia mempunyai teori yang detail dalam ilmu nahwu serta ilmu yang luas.

\section{MAZHAB-MAZHAB DALAM ILMU NAHWU}

Dalam al-Madaris al-Nahwiyah, ${ }^{20}$ Syauqi Dhaif mengklasifikasi 3 metode yang digunakan oleh para linguist Arab dalam menyusun gramatikanya, hanya saja intensitas penggunaan ketiga metode ini oleh para linguist bervariasi : 1). Simā' (aural); 2). Ta’līl (alegasi) dan 3). Qiyās (analogi)

Metode pertama, simā', dilakukan dengan jalan mendengarkan secara langsung perkataan ahli Qur'an atau Qurra', dan penduduk pedalaman yang bisa dipercaya kefasihannya.Beliau banyak menggunakan puisi-puisi badui dan perkataan mereka untuk kemudian menyusun teori atau kaidah secara induktif darinya.Dalam hal ini, Al-Khalil tidak mengindahkan para perawi hadits karena kebanyakan dari mereka adalah orang-orang non-arab.Metode kedua, yaitu ta'lil, berupa pencarian alasan atau penyebab ('illah) dalam i'rab.Misalnya mempertanyakan mengapa mubtada'dirafa, sehingga dicarilah alasan-alasannya.Metode ketiga, yaitu qiyas yaitu membuat pola atau kaidah dari ujaran orang Arab kemudian menerapkannya dalam kasus yang lainnya.Seperti ketika Sibawaih mengiaskan ism fail dengan fi'l mudari' dalam hal fungsi.Tentang qiyas ini, Syauqi dalam bukunya banyak menerangkannya dengan langsung menukil redaksi Sibawaih. ${ }^{21}$

Metode-metode yang dipaparkan oleh Syauqi diatas pada dasarnya masuk kriteria paradigma preskriptif. Menurut Șalāh al-Dīn Mustafa Paradigma mi’yāri yang diterapkan para linguist Arab terpengaruh dengan logika mantik Yunani paling tidak dari dua segi: Disamping

\footnotetext{
${ }^{19}$ Mazin al-Mubarak, al-Nahw al-Arabiy; al-'Illah al-Nahwiyyah, Jilid III, 44.

${ }^{20}$ Syauqi Ḍhaif, al-Madāris al-Nahwiyah, Cet. VII, (Kairo: Dar al-Maārif, t.t), 46 Muhsin,"Sejarah Dan Paradigma Penulisan Kaidah Bahasa Arab", MEDIASI, Vol. 9, No. 2, Januari-Desember 2015,46-56.

${ }^{21}$ Syauqi Ḍhaif, al-Madāris al-Nahwiyah, 46
} 
metode di atas, dikenal pula istilah āmil dan ma'mūl yang juga merupakan konsep penalaran.Amil secara harfiah berarti "yang mempengaruhi” dan ma'mul berarti yang dipengaruhi, secara teknis nahwu berarti sesuatu yang membuat akhir suatu kata berubah (I'rāb) misalnya rafa, nasab dan jar. ${ }^{22}$ 1). Kategori (ontologi Aristoteles); 2). Analogi dan Alegasi

Sementara itu paradigma deskriptif memiliki kriteria berikut:

1. Kesatuan tempat. Penelitian dibatasi pada satu tempat saja, berbeda dengan pendekatan preskriptif yang dilakukan pada beberapa tempat.

2. Kesatuan waktu. Penelitian hanya dilakukan hanya pada masa tertentu saja, sementara penelitian yang dilakukan oleh para linguist Arab dimulai sejak jaman jahiliyah melalui syairsyairnya sampai masa pemerintahan Umayyah.

3. Kesatuan teks. Ini dimaksudkan untuk melihat karakteristik masing-masing genre teks. Misalnya teks-teks syair dan prosa masing-masing diteliti tersendiri bukan dengan cara mencampur aduk keduanya.

Relevan dengan pembahasan tentang aliran (mazhab) Ilmu Nahwu yang dalam istilah ilmu Nahwu lebih akrab dengan sebutan Madrasah Nahwiyah, Menurut Dhoif, terdapat lima madrasah yang berkembang dalam mengkaji nahwu, yaitu aliran Bashrah, Kufah, Baghdad, Andalusia, dan Mesir. Aliran Bashrah dan Kufah disebut sebagai aliran utama, walapun harus diakui bahwa aliran Bashrah merupakan pionir bagi mazhab lainnya, karena ia merupakan peletak pertama kaidah nahwu. Menurut Dhoif Kedua aliran tersebut disebutnya sebagai aliran utama karena mempunyai otoritas dan independensi yang tinggi, independensi yang tinggi, kedua aliran tersebut juga mempunyai pendukung yang banyak dan fanatik, sehingga mampu mewarnai aliran-aliran berikutnya. Adapun tiga aliran yang lain disebutnya sebagai aliran turunan yang berinduk pada salah satu aliran utama atau merupakan hasil paduan antara keduanya. ${ }^{23}$

\section{Mazhab Bashrah}

Jumhur ulama nahwu yang berasal dari Bashrah, mereka membangun suatu kesamaan metode, pendekatan dan pemikiran bahasa dalam menetapkan kaidah-kaidah nahwu dengan cara tersendiri. Yaitu mempergunakan metode al-Sima', al-Qiyas, al-Ijma' al-istishab. Tokoh-tokoh dari aliran ini dikenal ada beberapa yang terkenal mulai angkatan I tahun $69 \mathrm{H}$ sampai angkata VII 285

\footnotetext{
${ }^{22}$ Muhammad Șalāh al-Dīn Mustafa, al-Nahw al-Wașfi min Khilāl al-Qur'an al-Kan̄m (Kuwait: Mu'assasah Ali Jarāh al-Ṣabāh, t.t), 14.

${ }^{23}$ Syauqi Dhoif, Al-Madârisul-Nahwiyah, 5. Dikutip oleh : Dolla Sobari, "Periodisasi Tokoh Ilmu Nahwu Aliran Basrah", Jurnal Bahasa dan Sastra Arab. Lihat juga : Kholisin, "Cikal Bakal Kelahiran Ilmu Nahwu”, BAHASA DAN SENI, Tahun 31, Nomor 1, Februari 2003.
} 
H. Dari beberapa angkatan yang ada, diantara tokoh yang populer dilihat dari karyanya yang sangat menumental dan menjadi acuan para ulama dan sumber pengkaji ilmu nahwu sesudahnya dan dapat pula membantu pengembangan pemikiran nahwu generasi sesudahnya adalah Sibawaehi, penerus dari الخليل, wafat pada tahun 161 H. Dia nama sebenarnya adalah Umar bin usaman bin Qanbar dan dari keluarga al-haris bin Ka'b dari keluarga Faris, kuburnya di Qasbah Faris. mengajarkan ilmu 24. الكتاب dan النحو قرآن nahwu setelah al-Khalil, dan dikenal dengan bukunya yang populer adalah

Perlu diketahui bahwa sesungguhnya periode Bashrah dan Kufah ini disebut sebagai periode ekstensifikasi. Pada dasarnya perkembangan awal atau periode perintisan dan penumbuhan nahwu berpusat di Bashrah, dimulai sejak zaman Abul Aswad sampai munculnya Al-Khalil bin Ahmad, yakni sampai akhir abad ke-satu Hijriyah. Periode ini masih bisa dibedakan atas dua sub periode, yaitu masa kepeloporan dan masa pengembangan. Masa kepeloporan tidak sampai memasuki masa Daulah Abbasiyah. Ciri-cirinya ialah belum munculnya metode qiyas (analogi), belum munculnya perbedaan pendapat, dan masih minimnya usaha kodifikasi. Adapun ciri-ciri masa pengembangan ialah makin banyaknya pakar, pembahasan tema-temanya semakin luas, mulai munculnya perbedaan pendapat, mulai dipakainya argumen dalam menjelaskan kaidah dan hukum bahasa, dan mulai dipakainya metode analogi. Yang menarik pada masa ini para ulama nahwu terjun langsung kesetiap kampung-kampung Arab Badui (pedalaman) untuk meneliti dan mengambil banyak sampel tentang kosakata Arab yang murni atau pun susunan kalimat bahasa Arab yang belum tercampur dengan dialek 'ajam dan masuknya lahn. Setelah itu ditulis, seperti yang dilakukan imam khalil Ahmad al-Farahidi dalam menyusun kitab $A l-A$ 'in. Disamping itu aliran ini terpengaruh oleh logika formal karena lebih cendrung menggunakan metode qiyas/silogisme karena melihat dari historisnya aliran ini mewarisi budaya hellenis Yunani, juga ilmu mantiq dan ilmu kalam berkembang pesat dikota Basrah ini. ${ }^{25}$

Nahwu mazhab Bashrah dibangun di atas tiga prinsip utama yaitu: al-Qiyâs, al-Ta'lîl dan alTa'wîl. Atau menurut Abd al-'Âl Salim al-Mukrim ketika mendeskripsikan karakter nahwu mazhab Bashrah ia menyatakan:"karakter paling menonjol mazhab Bashrah ialah menjadikan persoalan-persoalan nahwu dikaji dengan pendekatan logika formal (manthiq) dengan berbagai silogismenya, alasan rasionalitasnya, kemungkinan-kemungkinannya dan interpretasinya, kemudian

\footnotetext{
${ }^{24}$ Muhammmad Abu al-Fadil Ibrahim, Maratib al-Nahwiyyin, (Dar al-Fikr 1974), 106.

${ }^{25}$ Lihat Ahmad Afify. Al-Mandzumah Al Nahwiyah Al- Mansubah Li al-Khalil bin Ahmad Al Farahidy. (Cairo: Al Daar Al Manshuriyah Al Baniyah, 2003), 11. Dikuitip oleh : Toni Pransiska "Konsep I'rab dalam Ilmu Nahwu (Sebuah Kajian Epistemologis)”, al-Mahāra, Vol. 1, No.1, Desember 2015/1437H.
} 
setelah itu semua, baru mengacu kepada Kalam Allah dan kalam orang Arab. Itu sebabnya, yang menjadi fokus atau konsern utama nahwu mazhab ini adalah al-Qiyas (silogisme)" ${ }^{26}$

Oleh karena itu setelah muncul jumhur ulama nahwu yang beraliran Basrah berkembanglah pemikiran nahwu yang bercorak Basrah, yang mana pemikiranya mengutamakan dan mengedapankan al-Qiyas, al-Ijma'. Dan pemikiran -pemikiran dari mazhab ini dapat dilihat karyakarya para ulama nahwu mereka dan dituankannya dalam bentuk tulisan dan bisa disaksikan pada buku-buku yang mereka tinggalkan.

\section{1) Generasi pertama}

1. Abu al-Aswad al-Du’ali (w. $69 \mathrm{H})$

2. Abd ar-Rahmân Bin Hurmuz ( w. 117 H). Nama lengkapnya Abu Dawud Abd al-Rahman bin Hurmuz bin Abi Sa'ad al-Madini al-A'ra.

Adapun karakteristik periode pertama ini adalah, (1) mereka tergabung dalam profesi qari`. Para ulama Basrah secara menyeluruh adalah qâri’ al-Qur'an, yang mempelajari hukumhukumnya, yang haus akan bacaan al-Qur'an dan juga sebagai perawi hadits. (2) Memberi perhatian khusus terhadap lahn dalam kalam Arab, dan dalam al-Qur'an dan menentang fenomena terlarang ini. (3) Mushaf-mushaf diberi titik dengan i'rab yang dimulai oleh Abu Aswad al-Du'ali yang mendapat nasihat dari ibn Abihi, kemudian diikuti oleh murid-murid setelahnya, sebagai penentangan terhadap lahn al-Qur'an. (4) Awal penyusunan ilmu nahwu mendapatpetunjuk dari Imam Ali r.a yang diawali oleh Abu Aswad dan ikutioleh muridmuridnya. (5) Tidak terdapat peninggalan berupa tulisan kecuali riwayat yang diklaim oleh Nadîm dan Qifti. ${ }^{27}$

\section{2) Generasi Kedua}

Ada dua ulama nahwu yang berperan dalam periode ini, yaitu:

1. Ibnu 'Ābbās (w. $68 \mathrm{H} / 687 \mathrm{M}$ )

2. Nashr bin 'Āshim al-Laitsi (w. 89 H/708 M)

3. 'Anbasah al-F̄̄l (w. 100 H/ 719 M). 'Anbasah bin Mu'dân al-Misani al- Mahrī,

4. Maimūn Al-Aqran . Abū Abdullah Maimūn Al-Aqran

5. 'Abdur- Rahmân bin Hurmaz (w. 117 H/ 735 M)

6. Yahya bin Ya'mar Al-Udwānī Al-Laitsi (w. 129 H/747 M)

${ }^{26}$ Lihat Abd al-Al Salim Mukrim, al-Qurân al-Karîm wa Atsaruhu Fi al-Dirâsât al-Nahwiyyah, (Mesir: Dar alMaarif, t.t.), 91.

${ }^{27}$ Thanthawi, Nasyh'atu al-Nahwi wa Târîkhu Ashhari an-Nuhât, (Kairo: Darul Ma'ârif, 2005). 33. 
Ada beberapa hal yang menjadi karakteristik pada periode ini yaitu: (1) Tergabung dalam profesi ahli qira'at dan ahli hadits.(2) Memiliki perhatian pada realitas lahn dalam kalam Arab dan al- Qur'an, juga dalam pembicaraan para pemimpin seperti al-Hajjaj bin Yusuf al-Tsaqfi dan pemimpin lainnya. (3) Ada kesepakatan dalam memberi titik mushaf dengan titik i'râb. (4) Memberi titik mushaf dengan titik dan harakat atas nasihat dari Hajjaj bin Yusuf al-Tsaqfi. (5) Terdapat tambahan atas pe-nyu sunan ilmu nahwu. (6) Belum terdapat peninggalan berupa tulisan. $^{28}$

\section{3) Generasi ketiga}

Pada generasi ini, ada tiga ulama nahwu yang berperan, yaitu:

1. Abdullah bin Abī Ishāq (w. 127 H/745 M)

2. Isâ bin 'Umar al-Tsaqafî̀ (w. 149 H/766 M)

3. Abū 'Amru bin Al-'Alā’a (w. 154 H/771 M)

4. Yūnus bin Chabīb (w. 182 H/798 M).

5. Al-Khalīl bin Achmad (w. 175 H/ 791 M)

Ada beberapa karakteristik pada periode ini yaitu, (1) Dimulainya deprivasi qiyas, dan implementasinya atas pembacaan al- Qur'an dan puisi Arab. Dimulainya ta'lîl kaidah nahwu, dan ta'wîl terhadap hal yang menyalahi kaidah. (2) Dimulai munculnya berbagai pendapat seperti terdapatnya pendapat antara Abu 'Amr al-'Ulâ' dan 'Abdullah bin Abu Ishak, dan antara Abu 'Amr al-'Ulâ' dan 'Isa bin Amr. (3) Munculnya pendapat nahwu yang bersifat individual, dan pembacaan al-Qur'an yang berbeda dari jumhûr ulama. (4) Tidak terdapat peninggalan berupa tulisan kecuali yang diriwayatkan dari al-Jami' dan al-Kamil karya 'Isa ibn Amr. ${ }^{29}$

\section{4) Generasi Keempat}

1. Al-Khalīl bin Achmad al-Farāhidy (w. 175 H/ 791 M) Karya-karya al-Khalīl dinataranya menulis: Kitab Ma 'anil-Huruf dan Kitab al- 'Arudh.

2. Abū Basyr bin 'Utsmān bin Qunbar Sibawaihi (w. 180 H/796 M) Karya Sibawaihi yang paling momental adalah al-Kitab.

3. Abû Muchammad Yahya bin al-Mubārak bin al-Mughîrah al-'Adwiy Al-Yazīdy (w. 202 H/ $817 \mathrm{M})$

\footnotetext{
${ }^{28}$ Lihat buku Said Al-Afgâny, Min Târîkh An-Nahw, 130. Bandingkan dengan : Thanthawi, Nasyatu an-Nahwi wa Târîkhu Asyhari an-Nuhât, 34-dst. Sholah Ruwway, Al-Nahwu Al-'Arabiyyu: Nasyhatuhu, Tatawwuruhu, Madârisuhu, Rijâluhu.

${ }^{29}$ Lihat : Said Al-Afgâny, Min Târîkh Al-Nahw, 130-134.
} 


\section{5) Generasi Kelima}

1. Al-Akhfasy al-Awsath (w. 211 H/ 826 M). Kitab yang dikarangnya yang terkenal yaitu : alAwsath dan al-Maqayis.

2. Abū 'Ali Muhammad bin al-Mustanīr atau Qathrab (w. 206 H/ 821 M)

3. Ia bernama Abū 'Umar Shālih bin Ishaq al-Bajly Al-Jurmy (w. 225 H/ 840 M).

4. Muhammad 'Abdullah bin Muchammad bin Harun A’t-Tauzy (w. 238 H/ 852 M)

5. Abû 'Utsmān Bakr bin Muhammad Al-Māziny (w. 249 H/ 863 M)

6. Abū al-Fadhl 'Abbās bin al-Farj, Ar-Riyasyy (w. 257 H/ $871 \mathrm{M})^{30}$

\section{6) Generasi Keenam}

1. Abû al-'Abbas Muhammad bin Yazid Al-Mabrid (w. 285 H/ 898 M). Kitab Al-Mabrid di antaranya: I'rabul-Qur'an dan al-Madkhal li-Sibawaihi.

2. Al-Zujaj Abū Ishāq Ibrāhîm bin al-Sariyi bin Sahal.Al-Zujaj (w. 310 H/ 922 M). Kitabnya : Mukhtasor fi Nachwi, dan al- Qōwafi dan al-Arudh.

3. Abubakar bin Muhammad al-Sariyyi atau Ibnu al-Sirāj (w. 316 H/ 928M). Al-Ushūl al-Kabīr mujmal al-Aswat, al-Isytiqoq, syrh Sibawaihi, kitab Ihtijaj al-Farra.

4. Al-Sirāfi (w. 368 H/ 978 M). Abū Saīd al-Chasan bin Abdillah bin al-Mirzabān. Bukunya : al-Iqna' fi al-Nahwu dan Shinaati al-syiir wa al-Balaghah ${ }^{31}$

\section{Mazhab Kufah}

Mazhab Kufah Adalah suatu aliran yang mengedapankan penggunaan al-Qiyas, al-Ijma' dan Tahlil dalam menetapkan kaidah Nahwu. Pada masa ulama Kufah ini mampu melakukan pembaruan dalam pengkajian dan pengembangan ilmu nahwu dan dapat menetapkan kaidah-kaidah nahwu yang ditandai dengan munculnya berbagai kitab-kitab nahwu dan tokoh-tokohnya yang popular.

Jumhur ulama nahwu yang berasal dari kota ini, mereka membanguan suatu kesamaan metode, pendekatan dan pemikiran bahasa, dalam menetapakan kaidah-kaidah nahwu dengan cara tersendiri,yaitu mempergunakan metode al-Sima', al-Qiyas, al-Ijma' dan al-Istishab. Tokoh-tokoh dari aliran ini dikenal ada beberapa yang terkenal mulai angkatan I tahun $187 \mathrm{H}$ sampai angkata $\mathrm{V}$ 291 H. Dari beberapa angkatan yang ada, diantara tokoh yang populer dilihat dari karyanya yang sangat menumental dan menjadi acuan para ulama dan sumber pengkaji ilmu nahwu sesudahnya

\footnotetext{
${ }^{30}$ Lihat buku Said Al-Afgâny, Min Târîkh Al-Nahw, 130. Bandingkan dengan : Thanthawi, Nasyatu an-Nahwi wa Târîkhu Asyhari an-Nuhât, 34-dst.

${ }^{31}$ Lihat buku Said Al-Afgâny, Min Târîkh An-Nahw, 130. Bandingkan dengan : Thanthawi, Nasyatu anNahwi wa Târîkhu Asyhari an-Nuhât, 34-dst.
} 
dan dapat pula membantu pengembangan pemikiran nahwu generasi sesudahnya adalah al-Farra, sebagai penerus dari al- Ruasi (w. 161H). ${ }^{32}$ Nama sebenarnya adalah Abu Zakariyyah Yahya bin Ziyad al-Farra. mengajarkan ilmu nahwu setelah al-Kisa'i, dan dikenal dengan bukunya yang populer adalah معاني القرآن.33

Oleh karena itu setelah muncul jumhur ulama nahwu yang beraliran Basrah berkembanglah pemikiran nahwu yang bercorak Kufah, yang mana pemikiranya mengutamakan dan mengedapankan al-Qiyas, al-Ijma' dan tahlil. Dan pemikiran -pemikiran dari mazhab ini, dapat dilihat karya-karya para ulamanya, mereka tuangkan dalam bentuk tulisan dan bisa disaksikan pada buku-buku yang mereka tinggalkan.

Menurut Ahmad Amin menyimpulkan bahwa perbedaan menonjol karakter mazhab Bashrah dan Kufah adalah bahwa mazhab Bashrah bersifat lebih bebas (tidak terikat tradisi berbahasa yang telah ada), lebih rasional, lebih terorganisir atau teratur dan lebih berpengaruh. Sementara mazhab Kufah kurang memberi nuansa kebebasan, lebih mempertahankan apa yang diwarisi dari orang Arab meskipun kurang dapat dipertanggungjawabkan keabsahannya sekalipun. Mazhab Bashrah berupaya menjadikan bahasa memiliki sistem yang dapat dinalar dan menghindari segala aspek periwayatan (untuk menentukan kaidah bahasa) yang dapat mengacaukan sistem bahasa. Sebaliknya mazhab Kufah berkarakter sebaliknya, segala yang terdengar dari orang Arab tanpa memperdulikan tingkat keabsahan atau tidaknya riwayat tersebut, dijadikan rujukan dalam mengambil keputusan sebuah kaidah bahasa. ${ }^{34}$

\section{1) Tokoh- tokoh Mazhab Kufah}

Dari Bashrah ilmu nahwu terus berkembang ke Kufah, yang disebarkan oleh para alumni Madrasah al-Bashriyah. Mereka itu antara lain Ja'far al-Ruwasi (187 H.) dan Mu'adz al-Harra' (187 H) . Al-Harra' belajar kepada Abu Amr, sedang al-Ruwasi selain belajar kepada Abu Amr juga kekpada Isa ibn Umar dan Abu Amr al-Ala. Ketiganya ulama ini adalah tokoh nahwu di Bashrah. Sebagai pedoman murid- muridnya, al-Ruwasi menyusun kitab nahwu berjudul "al-Faishal". Mereka berdua mengembangkan ilmu nahwu dan membina kader-kadernya di Kufah. Sejak itulah bermunculan ulama-ulama nahwu aliran Kufah, seperti: al-Kisa'i (189 H) dan muridnya al-Farra' (207 H). Kedua ulama ini telah menyusun satu bentuk nahwu dan meletakkan dasar-dasarnya yang

\footnotetext{
${ }^{32}$ Sibawaehi, Mu;jam al-Udabaa, 16-115.

${ }^{33}$ Muhammmad Abu al-Fadil Ibrahim, Maratib al-Nahwiyyin, (Dar al-Fikr : 1974), 106.

${ }^{34}$ Ahmad Amin, Dhuha al-Islâm,. (Mesir: Maktabah Al-Nahdah Al-Mishriyyah, 1974), 296.
} 
berbeda dengan pendahulunya. Tidak berbeda dengan di Bashrah, di Kufah lahir "Madrasah Kufiah" sebagai tempat pengkaderan ulam-ulama nahwu Kufah. Madrasah ini dipelopori oleh alRuwasi dan al-Harra'. Dari sini bermunculanlah ulama-ulama nahwu, seperti: Hamzah Muhammad ibn Sa'dan (194 H), Ali ibn Hazim al-Lihyani $(220$ H), Hisyam ibn Mu'awiyah al-Darir, Ibn alSikkit (220 H), al-Thiwal (207 H) dan Tsa'lab (291 H). Mungkin di Kufah sudah terbentuk madzhab tersendiri di bidang nahwu. Tetapi, bagaimanapun pengaruh Bashrah masih tetap ada, Karena memang di sanalah awal mulanya ilmu nahwu lahir. Apalagi ulama-ulama Kufah juga murid yang pernah belajar di Bashrah.

\section{a) Mazhab Baghdad}

Di akhir periode ekstensifikasi, Imam Al-Ru'asi (dari Kufah) telah meletakkan dasar-dasar ilmu sharf. Selanjutnya pada periode penyempurnaan, ilmu sharf dikembangkan secara progresif oleh Imam Al-Mazini. Implikasinya, semenjak masa ini ilmu sharf dipelajari secara terpisah dari ilmu nahwu, sampai saat ini. ${ }^{35}$ Masa ini diawali dengan hijrahnya para pakar Bashrah dan Kufah menuju kota baru Baghdad. Meskipun telah berhijrah, pada awalnya mereka masih membawa fanatisme alirannya masing-masing. Namun lambat laun, mereka mulai berusaha mengkompromikan antara Kufah dan Bashrah, sehingga memunculkan aliran baru yang disebut sebagai Aliran Baghdad. ${ }^{36}$

Di antara perintis atau penggagas mazhab baru tersebut adalah Abu Hanîfah Ahmad bin Dâwud al-Dinawari, Abu al-Thayyib Muhammad bin Ahmad bin Ishâq al-A'rabi al-Wasyâ', Ibnu Kaisân Muhammad bin Ahmad bin Ibrâhim bin Kaisân ${ }^{37}$, al-Akhfash al-Shagîr, Ali bin Sulaiman bin al-Fadhl al-Nahwiyyi. ${ }^{38}$ Oleh karena sifatnya yang ekletis atau pengkombinasian itu, maka mazhab Bagdad tersebut memiliki karakternya sendiri, yaitu tidak terlalu bersifat rasional seperti yang menjadi ciri khas mazhab Bashrah, dan tidak pula terlalu tekstual seperti karakter khas

\footnotetext{
35 Lihat Ukon Purkonudin, Sejarah Penyusunan Nahwu. http://ukonpurkonudin.blogspot.com/2010/09/pendahuluan-salah-satu-cara-untuk.html. Diakses pada tanggal 25 Nopember 2017.

${ }^{36}$ Kesadaran perlunya mengakhiri persaingan lama inilah yang pada akhirnya memunculkan mazhab baru dalam nahwu, yaitu mazhab Bagdad. Sebuah mazhab yang mencoba mensinkretiskan dua mazhab (Bashrah dan Kufah) yang telah ada sebelumnya. Itu sebabnya, mazhab ini memiliki banyak sebutan diantaranya adalah "al-Khâlithaini baina al-Naz'ataini" (pengkombinasi antara dua mazhab), "Ashâb al-Madrasah al-Intikhâbiyyah" (penganut mazhab eklektisme) dan "al-Bagdadiyyûn". Lihat Abdul Aziz Ahmad Allam, "Min Târikh al-Nahwi al-Arabi", Majallah, edisi II, tahun ke $-2,1401 / 1402$ H. KSA.

${ }^{37}$ Adapun tokoh utama mazhab Bagdad ini diantaranya adalah Ibnu Kaisân yang memiliki nama lengkap Abu al-Hasan Muhammad bin Ahmad bin Kaisan (w.299 H). Ia dikenal sebagai tokoh pertama nahwu mazhab Bagdad meskipun oleh sebagian penulis biografi lain semisal Brooklman ia dimasukkan sebagai imam nahwu mazhab Bashrah.

38 Abd al-'Al Salim Mukrim, al-Qur’ân al-Karîm Wa Atsaruhu Fi al-Dirâsât al-Nahwiyyah, 143.
} 
mazhab Kufah. Namun demikian, para peneliti nahwu sering mengalami kesulitan untuk mengidentifikasi mazhab Bagdad ini. Sebab, meskipun disebut sebagai mazhab ekletis dari dua mazhab (Bashrah dan Kufah), para tokoh mazhab ini masih sering menampakan ego masing-masing mazhab asal mereka.

Aliran Bagdad Adalah suatu aliran yang mengedapankan penggunaan al-Sima, al-Qiyas. Menurut Ibn Jinni, al-Ijma', al-Istishhab dan memadukan pemikiran nahwu yang beraliran Basrah dan Kufah dalam menetapkan kaidah Nahwu. Pada masa ulama Bagdad ini mampu melakukan pembaruan dalam pengkajian dan pengembangan ilmu nahwu dan dapat menetapkan kaidah-kaidah nahwu yang ditandai dengan munculnya berbagai kitab-kitab nahwu dan tokoh-tokohnya yang populer da antaranya al-Zamaksyary. ${ }^{39}$ Jumhur ulama nahwu yang berasal dari kota ini, mereka membanguan suatu kesamaan metode, pendekatan dan pemikiran bahasa, dalam menetapakan kaidah-kaidah nahwu dengan cara tersendiri,yaitu mempergunakan metode al-Si-ma'al-Qiyas dan al-Ijma’ dan tahlil atau analisis dan al-Istishab.

\section{b) Mazhab Mesir}

Aktivitas keilmuan Nahwu telah muncul dan berkembang secara umum pada masa-masa awal perkembangan Islam. Dorongan untuk membaca Al-Qur'an secara benar telah menjadi faktor utama berkembangnya nahwu di negeri Fir'aun ini. Perkembangan ini didukung dengan adanya pandangan para peneliti yang mengemukakan adanya madrasah nahwu di Mesir dan Syam, diantaranya Dr. Khodijah Al-Haditsi yang menyebutkan adanya madrasah nahwu di Mesir dan Syam, yang keduanya sangat dipengaruhi oleh pemikiran-pemikiran nahwu madrasah Basrah. ${ }^{40}$

Pada masa awal perkembangan madrasah Mesir, telah ada murid Abu Aswad yang mengajar disana, yaitu Abdurrahman bin Hurmuz yang wafat di Iskandaria tahun $117 \mathrm{H}$. Beliau inilah yang memberikan tanda titik pada mushaf Al-Qur'an sebagai tanda I'rab. Beliau juga guru dari Imam Nafi' bin Abi Nu'aim, penduduk asli Madinah yang merupakan salah satu dari al-qurra' as-sab'ah yang sangat terkenal. ${ }^{41}$ Setelah itu Nahwu aliran Mesir ini berkibar semenjak hadirnya Muhammad bin Wallad At-Tamimi, dia berasal dari Basrah, tetapi tinggal di Fusthath Mesir. Beliau berguru kepada Al-Khalil bin Ahmad di Iraq dan menulis buku hasil pembelajarannya bersama sang penemu ilmu 'arudh tersebut. Salah satu tokoh yang juga belajar Ilmu Nahwu kepada Al-Kisa'i yakni Abul Hasan Al-A'azz. Dari adanya dua tokoh inilah mulai muncul aliran baru, perpaduan

\footnotetext{
${ }^{39}$ Al-Zamahksyary, hidup pada akhir abad V Hijriyah sampai awal abad VI Hijriyah.

${ }^{40}$ Syauqi Dhaif. Al-madaris an-Nahwiyah. ,327.

${ }^{41}$ Syauqi Dhaif. Al-madaris an-Nahwiyah. ,327.
} 
antara kedua aliran yang telah ada, yakni Kufah dan Basrah. Dua tokoh ini yang menjadi generasi pertama Nahwu Mesir. ${ }^{42}$

Generasi kedua Nahwu Mesir ditandai dengan munculnya Ad-Dinauri. Beliau adalah Ahmad bin Ja'far yang melakukan perjalanan ke Basrah untuk menuntut ilmu. Beliau belajar AlKitab milik Sibawaih dari Al-Mazini, kemudian ke Baghdad belajar kepada Tsalab, lalu pindah belajar kepada Al-Mubarrad. Setelah itu, beliau kembali ke Mesir dan mengajar Nahwu disana dan menulis sebuah buku yang berjudul Al-Muhadzdzab yang beliau peruntukkan bagi para muridnya disana. Ahmad bin Ja'far wafat pada tahun 289 H. Seorang tokoh yang sezaman dengan Ad-Dinauri adalah Muhammad bin Wallad At-Tamimi. Beliau wafat pada tahun 298 H. Pada mulanya, beliau belajar nahwu dari ayahnya dan juga Ad-Dinauri dan Mahmud bin Hassan. Kemudian, beliau menuju Baghdad dan belajar Al-Kitab kepada Al-Mubarrad. Setelah itu, beliau pulang. Disana beliau mengajar dan menulis sebuah buku ajar dengan judul Al-Munammaq. ${ }^{43}$

Generasi berikutnya adalah Ali bin Husain Al-Hunna'i, beliau wafat pada tahun 320 H. Dan juga Abul 'Abbas Ahmad bin Muhammad bin Wallad At-Tamimi, beliau wafat pada tahun $332 \mathrm{H}$. Ali bin Husain memadukan dua pendapat Basrah dan Kufah. Beliau dijuluki "Kura'un Namli" yang berarti kaki semut, karena fisiknya yang pendek. Beliau juga penulis Al-Mundhad. Sedangkan Abul 'Abbas belajar nahwu dan mendapat salinan al-Kitab dari ayah beliau yang bernama Muhammad, beliau juga belajar dari Az-Zajjaj di Basrah. Beliau dikenal seorang yang cerdik dan pandai. Selain dua tokoh ini, terdapat pula Abu Ja'far An-Nuhas Ahmad bin Muhammad bin Isma'il yang wafat pada tahun 338 H. Beliau penulis kitab Ma'anil Qur'an dan I'rabul Qur'an. ${ }^{44}$

\section{Karakter Mazhab Mesir}

Abdul Ali Salim Mukarrom menyebutkan ada 11 karakteristik dari madrasah Mesir,yaitu:

1).Percampuran nahwu secara logika; 2). Banyaknya penjelasan; 3).Banyaknya peraturan gramatikal bahasa; 4). Aturan prosa dalam gramatikal bahasa; 5). Latihan I'rob; 6). Banyaknya penggunaan majas dalam gramatikal bahasa; 7). Petunjuk penulisan gramatikal bahasa menggunakan batu; 8). Kesyahidannya dalam membaca; 9). Menggunakan hadist syarif; 10). Menyeimbangkan dan mengabarkan dan 11). Berijtihad. ${ }^{45}$

\footnotetext{
${ }^{42}$ Wallad bin Muhammad at-Tamimi dan Abul Hasan al-A'azz

${ }^{43}$ Wallad bin Muhammad at-Tamimi dan Abul Hasan al-A'azz, 328

${ }^{44}$ Wallad bin Muhammad at-Tamimi dan Abul Hasan al-A'azz, 332.

45 Abdul Ali Salim Mukarrom. al-Madrasah al-Nahwiyah fi Mishr wa Sham fi al Qornain al Sa'bi' wa alSamin min al Hijrah. Cet 1. (Darus Syuruq. 1400 H/1980),440-442.
} 
Selanjutnya menurut pendapat yang dikutip Khadijah, bahwasanya Karakteristik Madrasah Mesir ada 4 yakni:

1. Petunjuk Madzhab ini membahas tentang nahwu yang jelas dalam pusat kebudayaannya di Irak. Seperti: Bashrah, Kufah, dan Baghdad. ${ }^{46}$

2. Mengetahui ajaran nahwu di Mesir dengan gaya bahasa yang bagus sesuai bacaan yang dikarang oleh tokoh timur dan memaparkan pendapatnya untuk dibahas, didiskusikan, dikritik, mempertahankan pendapatnya sendiri atau karangan nahwu mereka. ${ }^{47}$

3. Mayoritas sumber tokoh nahwu madrasah Mesir, mereka berasal dari Bashrah yang hijrah ke Mesir, pembawa kitab Sibawaih atau juga ilmunya, atau bukan dari orang Mesir seperti halnya dari Andalus yang berkelekar kepadanya atau juga orang Barat atau juga yang lainnya

4. Madrasah nahwu di Mesir bercampur dengan sebagian pendapat nahwu Baghdad. ${ }^{48}$

\section{Tokoh-tokoh Nahwu Mesir}

Berikut ini beberapa Tokoh Mesir yang paling terkenal, diantaranya: Abu Ja'far An-Nuhas (Tokoh Mesir yang paling terkenal) yang wafat pada tahun $338 \mathrm{H}$. Beliau menulis sebuah karangan yang paling terkenal yaitu “Fi al - 'Arabiyyah wal 'Ulumul Qur'an” yang didalamnya menjelaskan tentang puisi.

Tokoh Mesir yang lain yakni Ibnu Hisyam, yang bernama asli Jamaluddin Abdullah bin Yusuf bin Ahmad bin Abdullah bin Hisyam Al-Anshori Al-Mishriy. Beliau lahir di Kota Kairo Mesir, pada tahun $708 \mathrm{H}$ dan wafat pada tahun $761 \mathrm{H}$. Beberapa karya beliau yang perlu dicatat adalah Mughni al-Labib 'an Kutub al-A'arib, Awdloh al-Masalik ila Alfiyyah ibn Malik, Syudzur adz-dzahab, Qathru an-Nada wa Ballu ash-Shada, dan al-I'rab 'an Qawaid al-I'rab.

Ibnu 'Aqil, nama asli beliau adalah Abdullah bin Abdurrahman yang wafat pada tahun 769 H. Beliau penulis syarah Alfiyyah Ibn Malik yang terkenal. Diantaranya juga ada As-Suyuthi, nama aslinya adalah Jalaluddin Abdurrahman bin Abu Bakar bin Muhammad, wafat pada tahun $911 \mathrm{H}$. Beliau sangat terkenal dengan banyak karyanya dalam berbagai disiplin ilmu. Dalam bidang bahasa, terdapat Asybah wa an-Nazhair,Ham'ul Hawami', Bughyat al-Wu'at, dan lain sebagainya. Ada juga Syekh Khalid Al-Azhari, wafat pada tahun 905 H. Beliau menghasilkan banyak karya, salah satunya adalah Syarh at-Tashrih 'ala at-Taudhih. Dan yang terakhir adalah Asy-Syumunni, wafat

\footnotetext{
H/1986),340.

${ }^{47}$ Al-Haditsi Khodijah Abdur Rozaq. Al-Madaris An-Nahwiyah, 343.

${ }^{48}$ Al-Haditsi Khodijah Abdur Rozaq. Al-Madaris An-Nahwiyah, 346.
}

46 Al-Haditsi Khodijah Abdur Rozaq. Al-Madaris An-Nahwiyah. Cet 1. (Universitas Baghdad. 1385 
pada tahun 929. Beliau juga pernah menulis komentar tentang Mughni al-Labib karangan Ibnu Hisyam. $^{49}$

\section{Pemikiran Tokoh Nahwu Madrasah Mesir}

1. Imam as-Suyuti

Imam as-Suyuti lahir di Kairo setelah adzan Maghrib, malam Ahad 1 Rajab 849 H/ 3 Oktober 1449 M. ${ }^{50}$ Sedangkan nama lengkap dan nasabnya adalah Abdurrahman bin Abi Bakar bin Muhammad bin Sabiqudin bin Al-Fakhir Ustman bin Nashiruddin Muhammad bin Asy-Syaikh Hammamudin Al-Hamman Al-Khadhari As-Suyuthi. Menurut pengakuannya sejarawan, sebagaimana yang diikuti oleh Harun, karangannya mencapai 300 judul buku, selain buku-buku yang dia musnahkan sendiri. ${ }^{51}$ Namun menurut Para sejarawan, buku-bukunya berjumlah 571 buah, baik berupa karya besar dengan jumlah halaman yang banyak maupun buku-buku kecil dan karangan-karangan singkat. Bahkan, dikatakan bahwa as-Suyuthi sangat berjasa dalam menampilkan kembali manuskrip-manuskrip lama yang pada waktu itu telah dianggap hilang.52

Syauqi Daif dalam karyanya, al-Madaris an-Nahwiyah, mengatakan bahwa Imam asSuyuthi termasuk ulama yang produktif dalam semua aspek medan keilmuwan pada masanya diantaranya: Ilmu tafsir, hadist, fiqh, sejarah, penerjemahan, bidang linguistik, dan tata bahasa $(\text { nahwu) })^{.53}$

\section{Ibnu al-Hajib}

Nama lengkap beliau adalah Jamaluddin Utsman bin Umar bin Abi Bakr. Beliau di Esna wilayah Mesir bagian hulu pada tahun 570 H, kemudian beliau tinggal di Kairo. Ayahnya adalah seorang pelayan Raja Izzuddin as-Sholahi pada masa itu. Dari segi akademis, Ibnu al-Hajib menekuni dan mendalami beberapa bidang keilmuan. ${ }^{54}$ Dan yang paling menonjol adalah Ilmu Fiqih yang bermadzhab Maliki, Ilmu Ushul, dan juga Ilmu Nahwu.

Ibnu al-Hajib memiliki banyak pemikiran yang sebagian diterima dan disepakati oleh ulama-ulama Nahwu, sering pula bertentangan dengan pendapat-pendapat ulama Nahwu lainnya. Diantara sekian banyak pendapatnya, beliau menyatakan bahwa I'rab itu adalah lafdhi bukan maknawi. Kemudian beliau beranggapan bahwa isim (sebelum penyusunannya dalam sighah dan

\footnotetext{
${ }^{49}$ http://www.uobabylon.edu.iq/uobcoleges/service-showarticle.aspx fid $=8$ \&pubid=4028

50 M. Habib," Asy-Suyuthi dan Pemikirannya di Bidang Nahwu”, Jurnal Adabiyat, Vol. 3, No.II, Juli 2004

${ }^{51}$ Harun, Taqdim ham al-Hawami, 11

${ }^{52}$ M. Habib, "al-Suyuthi dan Pemikiran di Bidang Nahwu”, Jurnal Adabiyat, 271.

${ }^{53}$ Syauqi Daif. Madrasah al-Mishri, Al-Madarisun Nahwiyah., 363

${ }^{54}$ Syauqi Daif. Madrasah al-Mishri, Al-Madarisun Nahwiyah., 363
} 
ibarat) adalah mabniy. Lalu tentang dua isim isyarah التان dan keduanya adalah isim isyarah yang ditempatkan atau diposisikan untuk mutsanna. Akan tetapi, keduanya bukanlah bentuk mutsanna yang sebenarnya. Mengapa? Karena الذان tersebut merupakan sighah (bentuk) dalam posisi rafa' dan dapat berubah menjadi الذين yang merupakan bentuk yang lain dan berposisi nashab dan jar begitu pula dengan التان.

Sebagian besar ulama Nahwu berpendapat bahwa kalimat seperti غلامي adalah mabniy, karena diidhofahkan kepada dhomir mabniy. Tapi Ibnu al-Hajib berpendapat lain, bahwasanya وغلامك berkedudukan sebagai mu’rob muqaddar dengan acuan beliau kepada kalimat غلامي kalimat غلامي

Kemudian pendapat tentang lam ibtida'. Beliau sependapat dengan Imam Zamakhsyari bahwa lam yang terdapat pada mubtada’ itu menjadi satu, contohnya لقائم زيد dan لزيد قائم, adapun selain dari posisi tersebut beliau berpendapat bahwa lamnya adalah lam muakkadah contohnya إن محمدا لقائم

Ibnu al-Hajib juga sependapat dengan beberapa pendapat ulama nahwu Kufah yang mana sifat nahwu Kufah adalah lebih fleksibel, luntur dan mengadopsi bahasa-bahasa kelompok atau individu-individu tertentu sebagai acuan teori mereka. Dan ini lebih bersifat deskriptif dalam teoriteori atau pun pembahasannya. ${ }^{55}$

\section{c) Mazhab Andalus (Spanyol)}

Tidak lama setelah Bani Umayyah mendirikan kekhalifahan di Andalusia (138 H-1422H), di negeri baru Islam di Barat ini muncul banyak budayawan dan sastrawan mensejajarkan diri dengan rivalnya di negeri Timur yang sudah lebih dahulu dikenal dengan para intelektualnya. Para ilmuan di Andalusia yang banyak menimba ilmu ke Timur ini pada umumnya adalah memiliki latar belakang sebagai ahli qira'ât (aneka ragam bacaan al-Qur'an) dan huffâdz (penghafal al-Qur'an). Itu sebabnya, pengetahuan yang berkembang lebih dahulu di negeri ini juga seputar ilmu qira'at disamping juga ilmu fikih. ${ }^{56}$

Sementara disiplin nahwu baru muncul dan berkembang belakangan setelah beberapa ilmuan Andalusia belajar ke Timur. Di antara mereka yang populer adalah Jaudi bin Utsman alMaururi. Ia mempelajari ilmu nahwu kepada al-Kissâi dan al-Farrâ'. Jaudi adalah orang pertama

55 Afandi, zamzam. "Ibnu Jinni: Menembus Sekat Madzhab Linguistik. (memadukan aspek logis dan sosiologis)". Jurnal Adabiyyat. Vol. 8. No. 1, Juni 2009

${ }^{56}$ Syauqi Dhaif, al-Madâris al-Nahwiyyah, 288. 
yang memperkenalkan karya-karya nahwu mazhab Kufah di Andalusia dan sekaligus juga ilmuan negeri tersebut yang menyusun buku tentang nahwu. Baru setelahnya muncul tokoh-tokoh lain seperti Abu Abdullah. Seperti Jaudi, ia juga belajar nahwu ke Timur kepada Utsman bin Said alMishri atau yang lebih terkenal dengan sebutan al-Warsh. ${ }^{57}$

Oleh karena yang pertama kali nahwu yang dikenal dan dipelajari oleh para ilmuan Andalusia adalah nahwu mazhab Kufah dan langsung dari para pakarnya sendiri, maka nahwu yang berkembang lebih di sana juga nahwu mazhab Kufah. ${ }^{58}$ Dan baru pada akhir abad ke-3 H, para ilmuan Andalusia berkenalan dengan nahwu mazhab Bashrah dirintis oleh al-Ufushniq Muhammad bin Musa bin Hisyam (w. 307 H). Ia pergi ke Timur dan belajar ilmu nahwu kepada Abu Ja'far alDinawari di Mesir. Buku yang ia pelajari adalah karya Sibawaih yang sangat terkenal itu, al-Kitab. Ia mempelajari nahwu dari Ahmad bin Yûsuf bin Hajjâj (w. 336 H). Meskipun tidak dikenal sebagai ahli nahwu, tetapi Ahmad selalu membaca dan mempelajari karya Sibawaih di atas. Selain al-Ushfuniq, tokoh Andalusia lain yang juga mempelajari karya Sibawaih semisal Muhammad bin Yahya al-Mahlabi al-Rabâhi al-Jayyâni (w.353 H), seorang ahli filsafat, manthiq dan kalam. ${ }^{59}$

\section{PENUTUP}

Kajian Ilmu Nahwu dan Sharaf adalah dua disiplin ilmu yang penting untuk memahami bahasa Arab dengan benar. Nahwu dimaknai sebagai ilmu kedudukan kata dalam kalimat, syakal akhirnya serta cara mengi'rabnya. Sementara Sharaf didefinisikan sebagai memindahkan atau mengubah asal kata kepada kata yang lain yang berbeda bentuk dan maknanya.Menurut Syauqi Dhaif bahwa para linguist Arab menggunakan 3 metod dalam menyusun gramatikanya yaitu : Simā' (aural), Ta'līl (alegasi) dan Qiyās (analogi).

Semangat untuk meletakan kaidah-kaidah bahasa Arab agar terhindar dari kesalahan berbahasa Arab, terbebas dari kesalahan memahami al-Qur'an dan menjauhkan basasa Arab dari

${ }^{57}$ Syauqi Dhaif, al-Madâris al-Nahwiyyah, 288.

58 Prinsip-prinsip qiyas (analogi), ta'lil dan lainya yang menjadi karakter nahwu Bashrah dikembangkan sedemikian rupa oleh para ahli nahwu Andalusia. Sekedar contoh saja, apabila nahwu Bashrah telah melahirkan teori nahwu tentang hukum atau ketentuan-ketentuan tertentu pada sebuah jabatan kalimat, maka nahwu Andalusia akan memperlus ketentuan tersebut. Misalnya dalam kasus "mubtada", nahwu Bashrah telah merumuskan teori dan ketentuan bahwa hukum mubtada' adalah harus dibaca rafa', maka nahwu Andalusia akan mengajukan pertanyaan-pertanyaan lanjutan mengapa ia harus dibaca rafa', kenapa tidak dibaca nasab saja, apa alasannya, kemudian mereka memberinya alasan-alasan (ta'lîlât) yang panjang lebar. Pertanyaan-pertanyaan lanjutan "kenapa, mengapa" semacam itu dalam tradisi nahwu klasik dengan sebutan "al-Illah al-Tsâniyyah" atau alasan kedua. Lihat. Syauqi Dhaif, al-Madâris alNahwiyyah, 293.

${ }^{59}$ Syauqi Dhaif, al-Madâris al-Nahwiyyah, 290. 
pengaruh bahasa amiyyah. Hal itu menjadi latar belakang historis lahirnya Ilmu Nahwu yang selanjutnya melahirkan mazhab-mazhab seperti Bashrah, Kufah, Baghdad, Mesir (Syam) dan Andalusia.

Ilmu Nahwu muncul dan berkembang dalam tradisi kajian Islam klasik dengan para tokoh ulama dan karakeristik metode dan hasil pemikiran berbeda. Nama besar dalam bidang Nahwu misalnya Abu Aswad al-Dualiy sebagai pionernya, Sibawaihi dan al Akhfash dari mazhab Bashrah, al Farra' al Kisa' dan al Farra' dari mazhab Kufah, al Suyuthi dari Mazhab Mesir, al Daniwari dan al Kaisan dari mazhab Baghdad, al Suyuthi dari mazhab Mesir dan Ibnu Madda dan al Ushfuniq dari Mazhab Andalusia.

\section{DAFTAR PUSTAKA}

Abd al-Al Salim Mukrim, al-Qurân al-Karîm wa Atsaruhu Fi al-Dirâsât al-Nahwiyyah. Mesir: Dar al-Maarif, t.t.

Abdul Hadi Fadli, Marâkiz ad-Dirâsat Al-Nahwiyyah. Yordania : Makatabah al- Manar 1986.

Abdul Ali Salim Mukarrom, Al-Madrasah an-Nahwiyah fi Mishri was Syaami fi al Qornain al Sa"bi' wa al-Samin min al Hijroh. Cet 1. Darus Syuruq. 1400 H/1980.

Abdul Aziz Ahmad Allam, "Min Târikh al-Nahwi al-Arabi", Majallah, edisi II, tahun ke -2 , 1401/1402 H. KSA.

Ahmad Amin, Dhuha al-Islâm. Mesir: Maktabah Al-Nahdah Al-Mishriyyah, 1974.

Ahmad Afify, Al-Mandzumah Al Nahwiyah Al- Mansubah Li al-Khalil bin Ahmad Al Farahidy.

Cairo: Al Daar Al Manshuriyah Al Baniyah, 2003.

Ahmad Al-Hasyimy, al-Qawaidul al-Asasiyyah. Beirut : Dar al-Kutub al-Ilmiyah, t.t.

Ahmad Al-Iskandari Musthafa, Al-Wasith fi al-Adab al- Arabi wa Tarikhihi. Kairo: Wizarat alMaearif al-Umumiyyah, 1919.

Ahmad Marzuq, "Grammatical Errors in the Arabic Essay (Content Analysis Research on the Student of Arabic Language Education Department, Faculty of Languages and Arts, StateUniversity of Jakarta)",

Al-Munjid fi al-Lughah, cet. 44. Beirut : Dār al-Masyriq, 2011.

Ana Wahyuning Sari, “Analisis Kesulitan Pembelajaran Nahwu Pada Siswa Kelas VII MTs Al Irsyad Gajah Demak Tahun Ajaran 2015/2016” Lisanul Arab Journal of Arabic Learning and Teaching. Jilid 6. Vol.1. (2017).

Arif Rahman Hakim, "Mempermudah Pembelajaran Ilmu Nahwu pada Abad 20", Jurnal alMaqoyis, vol. 1 No. 1, (2013).

Azhar Arsyad, Bahasa Arab dan Metode Pengajarannya. Yogyakarta : Pustaka Pelajar, 2004.

Dolla Sobari, "Periodisasi Tokoh Ilmu Nahwu Aliran Basrah", Jurnal Bahasa dan Sastra Arab.

Hasan Nuruddin, Al-Dalil ila Qawä id al-Lughah al-Arabiyyah.

Hazarudin. Bahasa Arab Teoritis (Nahwu Sharaf). Bogor : CV. Bintan Tsurayya, 1994 .

Ibnu Jinn̄̄, al-Khasāish. Kairo : Dār al-Hadits: 2008.

Khodijah Abdur Rozaq Al-Haditsi, Al-Madaris An-Nahwiyah. Cet 1. Universitas Baghdad. 1385 H/1986. 
Kholisin, “Cikal Bakal Kelahiran Ilmu Nahwu”, BAHASA DAN SENI, Tahun 31, No. 1, (2003).

Mazin Al-Mubarak, al-Nahw al-Arabiy; al-'Illah al-Nahwiyyah, Jilid III. Dar al-Fikr, 1981.

Muhammad Husni Arafat, "Diskusi Antara Al-Sairafi Dan Bisyr Ibn Matta Di Dalam Kitab AlMuqabasat Tentang Persoalan Nahwu" Manarux Quran.

M. Habib, " Asy-Suyuthi dan Pemikirannya di Bidang Nahwu", Jurnal Adabiyat, Vol. 3, No.II, (2004).

Muhammmad Abu al-Fadil Ibrahim, Maratib al-Nahwiyyin. Dar al-Fikr, 1974.

Muhsin,"Sejarah Dan Paradigma Penulisan Kaidah Bahasa Arab", MEDIASI, Vol. 9, No. 2, ( 2015).

Mustafa Muhammad Șalāh al-Dīn, al-Nahw al-Waṣfi min Khilāl al-Qur'an al-Kañmm. Kuwait: Mu'assasah Ali Jarāh al-Ṣabāh, t.t.

Said Al-Afghani, Min Târîkh al-Nahwi. Beirut: Dar al-Fikr, t.t.

Sholah Ruwway, Al-Nahwu Al-'Arabiyyu: Nash'atuhu, Tathawwuruhu, Madârisuhu, Rijâluhu. Kairo: Dâr Garîb, 2003.

Sudirman, "Pemikiran Nahwu Al-Zamakhsyary Dalam Perspektif Alquran".

Syauqiy Dhaif, al-Madaris al-Nahwiyah, Cet. III. Beirut: Dar al-Ma'arif, t.t.

Taufiq Burj, Musykilat Ta'lim al-Arabiyyah Li Ghairi an-Nathiqina biha, dalam as-Sijl al-Ilm LiNadwah al-Alamiyah Li Ta'lim al-Arabiyyah Li Ghairi al-Nathiqina biha. Kairo: Dar alMa'arif, 1980.

Toni Pransiska, “ Konsep I'rab dalam Ilmu Nahwu (Sebuah Kajian Epistemologis)”, al-Mahāra, Vol. 1, No.1, (2015).

Thanthawi, Nash'atu an-Nahwi wa Târîkhu Asyhari an-Nuhât. Kairo: Darul Ma'ârif, 2005.

Umi Nurun Ni'mah, "Dasar-Dasar Penyusunan Nahwu Syauqi Dhaif (Kajian Epistemologis atas Karya Syauqi Dhaif Tajdid an-Nahwu dan Taisir an-Nahwu at-Ta'limy Qadiman wa Haditsan)", Adabiyyat Jurnal Bahasa dan Sastra Arab, Vol.6, No. I (2007).

Yeni Ramdiani, "Kajian Historis; Perkembangan Ilmu Nahwu Mazhab Basrah", Volume VIII Nomor 2 (2015).

Zamzam Afandi, “ Ibnu Jinni: Menembus Sekat Madzhab Linguistik (Memadukan Aspek Logis dan Sosiologis)". Jurnal Adabiyyat. Vol. 8. No. 1, (2009). 